\title{
Determination and inheritance of phytic acid as marker in diverse genetic group of bread wheat"
}

\author{
Ijaz Ahmad ${ }^{\text {1\# }}$, Fida Mohammad ${ }^{1}$, Aurang Zeb ${ }^{2}$, Ijaz Rasool Noorka ${ }^{3}$, Farhatullah ${ }^{1}$, \\ Sultan Akber Jadoon ${ }^{4}$
}

${ }^{1}$ Department of Plant Breeding and Genetics, The University of Agriculture, Peshawar, Pakistan

${ }^{2}$ Nuclear Institute for Food and Agriculture, Tarnab, Pakistan

${ }^{3}$ University College of Agriculture, University of Sargodha, Sargodha, Pakistan

${ }^{4}$ University of Swabi, Swabi, Pakistan

Email:

Received 13 April 2013; revised 19 May 2013; accepted 20 June 2013

Copyright (C) $2013 \mathrm{Ijaz}$ Ahmad et al. This is an open access article distributed under the Creative Commons Attribution License, which permits unrestricted use, distribution, and reproduction in any medium, provided the original work is properly cited.

\begin{abstract}
Phytic acid (Myo-inositol 1,2,3,4,5,6 hexa-kisphophate) is a storage form of phosphorus and can accumulate to the levels as high as $35 \%$ in the wheat kernel. Phytic acid acts as an inhibitor for macronutrients as well as micronutrients and located in the bran of wheat kernel. Due to its inhibitory role, a high concentration of phytic acid is undesirable as it hinders the bio-availability of some essential nutrients such as $\mathrm{Fe}, \mathrm{Mg}, \mathrm{Ca}, \mathrm{Zn}$ and $\mathrm{Cu}$, etc. In order to check the inheritance of phytic acid in wheat kernels, phytic acid concentration was initially determined in kernels of 10 wheat genotypes to identify two contrasting genetic groups for diallel analysis. Based on pre-screening results of 10 wheat genotypes, five wheat genotypes ( 3 with high and 2 with low phytic acid concentration) were crossed in all possible combinations during 2007-2008 by $5 \times 5$ full diallel mating fashion to insight the inheritance of phytic acid and other yield contributing traits. All $20 F_{1}$ hybrids and five parental genotypes revealed significant differences statistically, except plant maturity. The narrow and broad sense heritability estimates varied widely among traits for spike length $(0.17,0.62)$, spikelets spike ${ }^{-1}(0.35$, $0.74)$, tillers plant ${ }^{-1}(0.05,0.52)$ and phytic acid concentration $(0.01,0.86)$. The values for phytic acid concentration ranged from $0.56 \%$ to $3.43 \%$ among $F_{1}$ hybrids and 1.06 to $3.67 \%$ for parental genotypes. $F_{1}$ hybrids, Ps-2005 $\times$ Ghaznavi (0.56\%), AUP-4006 $\times$ Ps-2004 (0.74\%), Janbaz $\times$ Ps-2004 (0.89\%) and Janbaz $\times$ Ps-2005 $(1.01 \%)$, had the lowest concentration
\end{abstract}

\footnotetext{
The authors are thankful to Higher Education Commission (HEC) of Pakistan for financial support to conduct the study.

${ }^{\#}$ Corresponding author.
}

of phytic acid. The study concluded that $F_{1}$ hybrids with low phytic acid concentration could yield desirable segregants.

Keywords: Phytic Acid; Diallel Analysis; Inheritance; Heritability; Yield; Traits

\section{INTRODUCTION}

Wheat (Triticum aestivum L.) belongs to family Poaceae (Gramineae) of monocots and is one of the most important food crops covering two-thirds of the acreage of cereals in the world and had represents a primary food in Pakistan [1,2]. It ranks first in terms of production and consumption in Pakistan and is one of the most abundant sources of carbohydrates [3]. Wheat acts as an important food crop for the people of Pakistan and serves as a real backbone in the economy of the country. Although the total production of wheat in Pakistan has increased many folds over the past few decades and we have touched the level of self sufficiency in the recent past, yet we need to produce more wheat for export to earn foreign exchange. For export, we need to concentrate on nutritional quality of wheat grain in order to compete in the international market. Phytic acid is believed to inhibit the bioavailability of micronutrients having a structure as can be predicted from its structural formula given below (see Figure 1).

Phytic acid is a storage form of phosphorus and believed to affect adversely the bio-availability of some essential micronutrients like $\mathrm{Fe}, \mathrm{Ca}, \mathrm{Mn}, \mathrm{Zn}, \mathrm{Mg}, \mathrm{Cu}$, etc. Therefore, we need to concentrate on improving the nutritional value of our wheat grains. Phytic acid is always present in vegetal matrices composed of fiber, minerals, trace elements and other phyto-micronutrients [4]. Phytic- 
<smiles>O=P(O)(O)OC1[C@H](OP(=O)(O)O)[C@H](OP(=O)(O)O)[C@@H](OP(=O)(O)O)[C@H](OP(=O)(O)O)[C@H]1OP(=O)(O)O</smiles>

Figure 1. $(1 r, 2 R, 3 S, 4 s, 5 R$, $6 S)$-cyclohexane-1,2,3,4,5,6hexayl hexakis [dihydrogen (phosphate)] name (IUPAC) International Union of Pure and Applied Chemistry.

acid is an anti-nutrient that hinders the bio-availability of nutrients and the lowest quantity desirable in wheat. Phytic acid contents can be decreased by fortification which changes oxidation state of $\mathrm{Fe}$ [5]. Phytic acid concentration is negatively correlated with $\mathrm{Ca}, \mathrm{Mg}, \mathrm{Zn}$, $\mathrm{Mn}$ and $\mathrm{Fe}$ concentrations [6]. Phytic acid is the main source of phosphorus in cereal grains and in bakery products [7]. Phosphorus mainly stores in the form of phytic acid in seed and has a profound effect on the seed used as a food commodity. Phytic acid is a potent inhibitor of mineral and trace element absorption occurs in all cereal grains and legume seeds. Reducing phytic acid content by soaking and germination was studied in a wide range of grains and seeds. Germination increased phytase activity 3 to 5 -fold in some cereal grains and legume seeds, while the influence on phytic acid content was insignificant in most materials tested. Highly apparent phytase activity was found in untreated whole grain rye, wheat, triticale, buckwheat, and barley [8]. Identification of wheat with relatively low phytic acid would be a step towards development of wheat cultivars with low phytic acid. Keeping in view the importance of phytic acid as a potent inhibitor for the bioavailability of micronutrients viz. $\mathrm{Fe}, \mathrm{Ca}, \mathrm{Mn}, \mathrm{Zn}, \mathrm{Mg}$, $\mathrm{Cu}$, etc., a study was conducted. This study was initiated by crossing two contrasting groups of wheat genotypes ( 2 with low and 3 with high phytic acid concentrations), selected on the basis of 10 wheat genotypes preliminary screening for phytic acid concentration in bread wheat. Therefore, it is the need of hour to ensure the nutritional quality of bread wheat [9]. Five wheat genotypes were crossed in $5 \times 5$ full diallel with the objective of developing low phytic acid segregants of wheat, decreasing the inhibitory effect of phytic acid and enhancing the bioavailability of micronutrients and macronutrients to humans. The specific objectives of the present project were to determine the phytic acid profile and other agronomic traits of different bread wheat genotypes and to estimate of their heritability.

\section{MATERIALS AND METHODS}

The experiment was conducted in the department of plant breeding and genetics, The University of Agriculture Peshawar, Khyber Pakhtunkhwa Pakistan during the year 2007-09. Ten wheat genotypes, Uqab, Tatara, AUP5006, Ghaznavi, Saleem-2000, Pirsabak-2004, Fakhre Sarhad, Pirsabak-2005, Janbaz and AUP-4006 were screened for phytic acid concentration in 2007 at the Nuclear Institute for Food and Agriculture (NIFA) Peshawar according to [10]. Based on the results of preliminary study of ten bread wheat genotypes, two contrasting groups (one group with high phytic acid genotypes i.e. Pirsabak-2005 (2.89\%), Janbaz (3.67\%) and AUP-4006 (2.83\%) and the other group with low phytic acid genotypes i.e. Pirsabak-2004 (1.77\%) and Ghaznavi (1.06\%) were identified. These five genotypes were crossed in all possible combinations in 2007 using $5 \times 5$ full diallel mating design.

Fifteen spikes of each genotype was manually emasculated and bagged in order to prevent contamination by foreign pollens. After two days, emasculated female spikes were pollinated by applying fresh pollen from the desirable male spike. By this method $20 \mathrm{~F}_{1}$ hybrids (both direct and reciprocal) were made to get enough seed for further planting experiment in 2008-2009. All $\mathrm{F}_{1}$ hybrids along with parental genotypes were planted with a distance of plant to plant and row to row $25 \mathrm{~cm}$ investigate phytic acid and other agronomic traits. The experiment was laid down in randomized complete block design with three replicates. Each replication was assigned with $20 \mathrm{~F}_{1} \mathrm{~S}$ and 5 parental genotypes. Each entry consisted of one row with a row length of $3.75 \mathrm{~m}$. Plant to plant and row to space of $25 \mathrm{~cm}$ was maintained. Urea and DAP fertilizers were applied at 120 and $60 \mathrm{~kg} \mathrm{ha}^{-1}$, respectively, to crop for maintaining normal nutrients status of the soil. Half dose of urea and full dose of DAP were applied at the time of seed bed preparation while remaining half dose of urea was applied at the time of first irrigation. Standard practices including hoeing, weeding, irrigation etc were carried out for the experiment to reduce experimental error. Data were recorded on five randomly selected plants from each population for spike length, total tillers plant ${ }^{-1}$, days to maturity, spikelets spike $^{-1}$, and phytic acid. The grain samples were properly threshed and drawn from each entry of the study of phytic acid determination at Nuclear Institute of Food and Agriculture (NIFA) Peshawar, human nutrition lab. The sensitive method of [10] was adopted for the determination of phytic acid in the whole wheat flour samples.

\subsection{Determination of Phytic Acid}

The sample was extracted with $0.2 \mathrm{~N} \mathrm{HCl}$ and heated with an acidic iron-III solution of known iron content. The decrease in the iron content was the measure of free 
phytic acid in supernatant [10]. The reagents are as follows.

\subsubsection{Phytic Acid Reference Solution}

Sodium salt of phytic acid $\left(\mathrm{C}_{6} \mathrm{H}_{6} \mathrm{O}_{24} \mathrm{P}_{6} \mathrm{Na}_{12}\right)$ was used for reference. Stock solution was prepared by dissolving $0.15 \mathrm{~g}$ sodium phytate in $100 \mathrm{ml}$ distilled water. The reference solution was prepared by diluting the stock solution with $\mathrm{HCl}$ in a range from 3 to 30 micro-grams (ug $\mathrm{ml}^{-1}$ ) phytic acid phosphorus.

\subsubsection{Ferric Solution}

Ammonium Iron-III Sulphate. $12 \mathrm{H}_{2} \mathrm{O}$. Ferric solution was prepared by dissolving $0.2 \mathrm{~g}$ of Ammonium Iron-III sulphate. $12 \mathrm{H}_{2} \mathrm{O}$ in $100 \mathrm{ml}$ of $2 \mathrm{~N} \mathrm{HCl}$ and the volume was made up to $1000 \mathrm{ml}$ with distilled water.

\subsubsection{2,2-Bipyridine Solution}

Ten grams of 2,2-bipyridine and $10 \mathrm{ml}$ of Thioglycolic acid was dissolved in distilled water and the volume was made upto $1000 \mathrm{ml}$.

\subsubsection{Protocol}

Grain sample (10 g) of each genotype was finely grinded by grinder and a fine grade of dried flour was obtained. The defatted and finely ground wheat flour sample $(0.06$ g) was weighed and added in dry and clean screw cap test tube $(15 \mathrm{ml})$. Sample was extracted with $10 \mathrm{ml}$ of 0.1 $\mathrm{N} \mathrm{HCl}$ for 1 hour shaking in shaker. From this extract 0.5 $\mathrm{ml}$ in duplicate was taken into dry and clean screw cap test tubes. A quantity of $1 \mathrm{ml}$ Ferric solution (concentration $=23 \mu \mathrm{g} \mathrm{ml}^{-1}$ or $23 \mathrm{ppm}$ solution) was added to these test tubes and closed by screw caps. These tubes were heated $\left(105^{\circ} \mathrm{C}\right)$ in boiling water bath for 30 minutes and were allowed to cool at room temperature. Reaction mixture was provided by $2 \mathrm{ml}$ of 2,2-biphyridine solution (concentration $=1 \% 2,2$ bipyridine solution) and mixed thoroughly by shaking. Reaction mixture was transferred to cuvet of spectrophotometer (UV-1800, Made in Japan) and optical density (OD $510 \mathrm{~nm}$ ) was recorded. The absorbance was measured within 4 minutes according to the method delineated by [10].

\subsection{Statistical Analysis}

\subsubsection{Analysis of Variance}

For analysis of variance data were subjected to Stateview software version 5, developed by SAS Institute Inc. USA which is based on the statistical model of [11].

\subsubsection{Diallel Analysis}

Diallel analysis for $5 \times 5$ diallel cross was conducted by using Diallel-98 soft ware developed by Tokyo University of Japan. Soft ware yielded Griffing, s Anova, Estimates of genetic parameters.

\section{RESULTS AND DISCUSSION}

Data of phytic acid and important yield traits for five parental genotypes and all possible crosses $\left(20 \mathrm{~F}_{1}\right)$ were subjected to biometrical analysis for getting genetic information about various aspects. The null hypothesis for equality of means was tested through F-distribution of [11] in analysis of variance. In case of rejection of null hypothesis further evaluation of means and diallel analysis [12] was studied. The results of analysis of variance and diallel analysis are presented and discussed.

\subsection{Mean Performance of F1 and Parental Genotypes}

Analysis of variance revealed that genotypes had significant differences for all traits (Table 1). Means of the genotypes (parents + crosses) for the traits studied are presented (Table 2). Data regarding spike length revealed that parental genotype Janbaz appeared with long spike followed by Ghaznavi while Ps-2005 and Ps-2004 yielded short spikes. Long spikes were produced by cross Ghaznavi $\times$ Janbaz while short spikes by Ps-2005 $\times$ AUP-4006 among the $F_{1}$ hybrids. Some $F_{1}$ crosses like AUP-4006 $\times$ Ps-2004, Ps-2004 $\times$ Ps-2005, AUP-4006 $\times$ Janbaz and Janbaz $\times$ Ps-2004 were at par for the said trait. Data concerning total tillers plant ${ }^{-1}$ showed that among parental genotypes Ps-2004 produced more total tillers plant $^{-1}$ while less total tillers plant ${ }^{-1}$ was recorded for parental genotype AUP-4006. Ghaznavi $\times$ Janbaz appeared with maximum total tillers plant $\mu^{1}$ while cross Ps-2005 $\times$ Janbaz with minimum total tillers plant ${ }^{-1}$ among the $F_{1}$ crosses. Among $F_{1}$ crosses Ps-2004 $\times$ Ghaznavi, AUP-4006 $\times$ Ps-2005, Janbaz $\times$ Ps-2004, Ghaznavi $\times$ Ps-2005 and Ghaznavi $\times$ Ps-2004 were at par for total tillers plant ${ }^{-1}$. Data regarding plant maturity is presented in Table 2: which indicated that among the parental genotype, AUP-4006 took maximum number of days for maturity while Ps-2005 minimum number of days for the said trait. Among the $\mathrm{F}_{1}$ hybrids, AUP-4006 $\times$ Ps-2004 and Ps-2005 $\times$ Janbaz showed late maturity by taking more number of days for maturity whereas Ps-2004 $\times$ Ghaznavi showed early maturity by taking less number

Table 1. Mean squares for phytic acid and other agronomic traits in bread wheat.

\begin{tabular}{ccccc}
\hline \multirow{2}{*}{ Traits } & \multicolumn{2}{c}{ Genotypes } & \multicolumn{2}{c}{ Replications } \\
\cline { 2 - 5 } & df & MS & Rep df & MS \\
\hline Total tillers plant $^{-1}$ & 24 & $7.43^{* *}$ & 2 & $0.36^{\mathrm{NS}}$ \\
Spike length & 24 & $3.72^{* *}$ & 2 & $15.34^{\mathrm{NS}}$ \\
Days to maturity & 24 & $10.99^{* *}$ & 2 & $3.41^{\mathrm{NS}}$ \\
Spikelets spike $^{-1}$ & 24 & $6.41^{* *}$ & 2 & $2.09^{*}$ \\
Phytic acid & 24 & $1.651^{* *}$ & 2 & $0.32^{\mathrm{NS}}$ \\
\hline
\end{tabular}

**** Indicates significance at 0.05 and 0.01 , respectively; NS shows nonsignificant. 
Table 2. Means of Parents and F1s for spike length, (SL), total tillers plant ${ }^{-1}$ (TTP-1) days to maturity (DM), spikelets spike ${ }^{-1}$ (SSP-1) and phytic acid in $5 \times 5$ diallel cross of bread wheat.

\begin{tabular}{ccccccc}
\hline S.No & Genotypes & DM & TTP $^{-1}$ & SL $(\mathbf{c m})$ & SSP $^{-1}$ & PA\% \\
\hline 1 & AUP-4006 & 170.67 & 7.87 & 9.00 & 23.67 & 3.42 \\
2 & Janbaz & 170.66 & 11.57 & 11.67 & 24.67 & 1.61 \\
3 & Ghaznavi & 169.66 & 10.06 & 11.13 & 24.67 & 1.25 \\
4 & Ps-2004 & 169.00 & 11.92 & 9.00 & 24.00 & 1.66 \\
5 & Ps-2005 & 167.33 & 10.80 & 9.00 & 23.00 & 2.48 \\
6 & AUP-4006 $\times$ Ps-2004 & 170.33 & 8.33 & 12.40 & 22.33 & 0.74 \\
7 & Ps-2004 $\times$ AUP-4006 & 167.00 & 9.00 & 11.30 & 22.00 & 2.60 \\
8 & Ps-2004 $\times$ Ghaznavi & 164.00 & 11.73 & 11.13 & 23.33 & 2.48 \\
9 & Ps-2004 $\times$ Ps-2005 & 167.00 & 9.67 & 12.60 & 22.00 & 1.46 \\
10 & AUP-4006 $\times$ Janbaz & 165.00 & 9.13 & 12.20 & 26.33 & 2.83 \\
11 & AUP-4006 $\times$ Ghaznavi & 167.00 & 7.93 & 11.80 & 25.00 & 2.81 \\
12 & AUP-4006 $\times$ Ps-2005 & 170.00 & 11.67 & 11.73 & 26.00 & 2.55 \\
13 & Janbaz $\times$ AUP-4006 & 170.00 & 10.57 & 11.00 & 23.00 & 2.65 \\
14 & Janbaz $\times$ Ghaznavi & 164.66 & 10.40 & 11.33 & 26.00 & 1.63 \\
15 & Janbaz $\times$ Ps-2004 & 165.66 & 11.67 & 12.60 & 25.33 & 0.89 \\
16 & Janbaz $\times$ Ps-2005 & 170.66 & 8.20 & 11.60 & 26.33 & 1.01 \\
17 & Ghaznavi $\times$ AUP-4006 & 170.33 & 9.06 & 11.00 & 25.00 & 3.43 \\
18 & Ghaznavi $\times$ Janbaz & 165.66 & 13.60 & 13.40 & 25.00 & 1.52 \\
19 & Ghaznavi $\times$ Ps-2005 & 166.33 & 11.13 & 11.93 & 24.00 & 2.81 \\
20 & Ghaznavi $\times$ Ps-2004 & 166.00 & 11.93 & 10.73 & 25.00 & 2.32 \\
21 & Ps-2004 $\times$ Janbaz & 167.66 & 8.77 & 12.27 & 23.00 & 2.53 \\
22 & Ps-2005 $\times$ AUP-4006 & 167.33 & 10.76 & 10.53 & 24.00 & 2.83 \\
23 & Ps-2005 $\times$ Janbaz & 171.00 & 7.66 & 11.56 & 23.66 & 2.77 \\
24 & Ps-2005 $\times$ Ghaznavi & 170.00 & 10.60 & 11.80 & 23.33 & 0.56 \\
25 & Ps-2005 $\times$ Ps-2004 & 168.00 & 11.37 & 10.47 & 21.66 & 1.58 \\
\hline & & & & & &
\end{tabular}

of days for completing life span. Main purpose in many plant breeding programs is to develop wheat cultivars with optimum days to maturity which can reduce fertilizer and irrigation application cost [13]. Data pertaining to spikelets spike ${ }^{-1}$ showed highly significant differences. Maximum spikelets sipke $^{-1}$ was observed for parental genotypes (Table 2), Janbaz and Ghaznavi whereas less spikelets spike $^{-1}$ was recorded for parental genotype Ps-2005. Among the $F_{1}$ progenies two crosses i.e. AUP$4006 \times$ Janbaz and Janbaz $\times$ Ps-2005 yielded maximum spikelets spike ${ }^{-1}$ whereas minimum spikelets spike ${ }^{-1}$ was shown by cross Ps-2005 $\times$ Ps-2004. Some $F_{1}$ crosses like AUP-4006 $\times$ Ghaznavi, Janbaz $\times$ Ps-2004, Ghaznavi $\times$ AUP-4006, Ghaznavi $\times$ Janbaz and Ghaznavi $\times$ Ps-2004 were at par for spikelets spike ${ }^{-1}$. Phytic acid concentration was determined by the sensitive method of [10]. Analysis of variance showed highly significant differences (Table 1). Maximum phytic acid concentration was found in AUP-4006 while minimum in Ghaznavi among the parental genotype (Table 2). $F_{1}$ hybrids showed a wider range for phytic acid. Highest phytic acid concentration was observed in cross combination Ghaznavi $\times$ AUP-4006, followed by AUP-4006 $\times$ Janbaz whereas lower concentration was recorded for Ps-2005 $\times$ Ghaznavi and AUP-4006 $\times$ Ps-2004 among the $F_{1}$ hybrids. Many genotypes among the $F_{1}$ hybrids were at par for phytic acid concentration.

\subsection{Diallel Analysis}

Data collected for phytic acid and all agronomic traits were subjected to analysis of variance following [11], before conducting diallel analysis by using State view software version 5, developed by SAS Institute Inc. USA. Significant genotypic differences were found for all the traits except plant maturity which provided justification for diallel analysis. Diallel analysis $(5 \times 5$ diallel analysis $)$ was carried using a software Dial-98. Genetic parameters were also calculated by the same software.

\subsubsection{Spike Length}

Complete analysis of variance for $5 \times 5$ diallel cross was carried out for spike length which indicated (Table 3) that item a, which was the measure of additive gene effect appeared with significant differences and thus considered as a major contributing factor towards the total variation due to additive gene effect. Genetic component b which was used for the measurement of overall dominance also yielded significant variation, showed the important role of dominance. Highly significant differences in the value of $\mathbf{b}_{1}$ indicated the presence of directional genes for spike length. Asymmetrical genes distribution among the parents was supported by the non-significant value of $\mathbf{b}_{2}$. Specific gene effect was lacking due to non-significant value of $\mathbf{b}_{\mathbf{3}}$. The values of $\mathbf{c}$ (maternal effect) and reciprocal effect (d) were non-significant.

Regression analysis and $\mathrm{t}^{2}$ tests of adequacy showed that the data was adequate for diallel analysis for the trait of spike length (Table 4). For spike length, genetic component, $\mathrm{H}_{2}, \mathrm{~F}, \mathrm{~h}^{2}$ and $\mathrm{E}$ revealed significant differ-

Table 3. Mean squares and degree of freedom for the analysis of variance of $5 \times 5$ diallel for spike length, tillers plant ${ }^{-1}$, spikelets spike ${ }^{-1}$ and phytic acid.

\begin{tabular}{ccccccccc}
\hline \multirow{2}{*}{ SOV } & \multicolumn{2}{c}{ Spike length } & \multicolumn{2}{c}{$\begin{array}{c}\text { Total tillers } \\
\text { palnt }\end{array}$} & \multicolumn{2}{c}{$\begin{array}{c}\text { Spikelets } \\
\text { spike }\end{array}$} & \multicolumn{2}{c}{ Phytic acid } \\
\cline { 2 - 9 } & df & Ms & df & Ms & df & Ms & df & Ms \\
\hline $\mathrm{a}$ & 4 & $5.33^{*}$ & 4 & $4.88^{\mathrm{NS}}$ & 4 & $11.21^{* *}$ & 4 & $0.39^{\mathrm{NS}}$ \\
$\mathrm{b}$ & 10 & $5.05^{* *}$ & 10 & $8.30^{* *}$ & 10 & $5.68^{* *}$ & 10 & $2.92^{* *}$ \\
$\mathrm{~b}_{1}$ & 1 & $34.54^{* *}$ & 1 & $5.94^{\mathrm{NS}}$ & 1 & $1.47^{\mathrm{NS}}$ & 1 & $3.85^{* *}$ \\
$\mathrm{~b}_{2}$ & 4 & $1.60^{\mathrm{NS}}$ & 4 & $9.01^{*}$ & 4 & $6.25^{* *}$ & 4 & $3.39^{* *}$ \\
$\mathrm{~b}_{3}$ & 5 & $1.92^{\mathrm{NS}}$ & 5 & $8.20^{*}$ & 5 & $6.06^{* *}$ & 5 & $2.36^{* *}$ \\
$\mathrm{c}$ & 4 & $2.68^{\mathrm{NS}}$ & 4 & $8.61^{*}$ & 4 & $6.38^{* *}$ & 4 & $4.29^{* *}$ \\
$\mathrm{~d}$ & 6 & $1.12^{\mathrm{NS}}$ & 6 & $3.87^{\mathrm{NS}}$ & 6 & $4.44^{* *}$ & 6 & $1.65^{* *}$ \\
\hline
\end{tabular}

${ }^{*} \mathrm{P}: 0.05 ;{ }^{* *} \mathrm{P}: 0.01 ; \mathrm{a}=$ additive gene effect, $\mathrm{b}=$ dominance gene effect, $\mathrm{b}_{1}=$ directional dominance deviation, $\mathrm{b}_{2}=$ genes distribution among parents, $\mathrm{b}_{3}=$ effect of specific gene, $c=$ maternal effect, $d=$ reciprocal effect. 
Table 4. Scaling tests of additive-dominance model for phytic acid and other agronomic traits in bread wheat for $5 \times 5$ diallel cross.

\begin{tabular}{|c|c|c|c|c|}
\hline \multirow{2}{*}{ Parameters } & \multirow[t]{2}{*}{$t^{2}$} & \multicolumn{2}{|c|}{$\begin{array}{l}\text { Regression analysis } \\
\text { ( } t \text { value of } b \text { ) }\end{array}$} & \multirow{2}{*}{ Conclusions } \\
\hline & & $\mathbf{B}=\mathbf{0}$ & $B=1$ & \\
\hline Spike length & $0.002^{\mathrm{NS}}$ & $3.60^{*}$ & $-0.02^{\mathrm{NS}}$ & Model was adequate \\
\hline $\begin{array}{l}\text { Total tillers } \\
\text { plant }^{-1}\end{array}$ & $0.012^{\mathrm{NS}}$ & $3.59^{*}$ & $0.71^{\mathrm{NS}}$ & Model was adequate \\
\hline Spikelets spike ${ }^{-1}$ & $-0.052^{\mathrm{NS}}$ & & & $\begin{array}{l}\text { Model was partially } \\
\text { adequate }\end{array}$ \\
\hline Phytic acid & $-0.065^{\mathrm{NS}}$ & $0.98^{*}$ & $1.64^{\mathrm{NS}}$ & Model was adequate \\
\hline
\end{tabular}

ences whereas additive effect and dominance effect were non-significant (Table 5). Additive effect (D) was little bit smaller than $\mathrm{H}_{1}$ and $\mathrm{H}_{2}$ which showed the crucial role of additive genes of partial nature. Genetic component $\mathrm{F}$ was positive and significant for spike length and indicated the presence of more dominant genes. Positive and significant value of $\mathrm{h}^{2}$ accounted for the presence of overall dominance effect due to heterozygous loci affecting the expression of spike length. Genetic item E was significant and showed a vital role of the environment in controlling spike length. Average degree of dominance $\left(\mathrm{H}_{1} / \mathrm{D}\right)^{1 / 2}$ was less than unity and supported partial dominance with additive gene effect for spike length. Estimated values for narrow sense and broad sense heritability were 0.17 and 0.62 , respectively, for spike length (Table 5). These results are in line with those of $[14,15]$ who reported recessive genes for spike length. [16] reported additive gene action for spike length. [17] on the other hand reported contradictory findings that spike length was under the control of over dominance type of gene action.

\subsubsection{Total Tillers Plant $^{-1}$}

Analysis of variance for $5 \times 5$ diallel cross for total tillers plant $^{-1}$ revealed (Table 3) non-significant differences for genetic constituent a, which accounted for the measurement of additive gene effect. Genetic component $\mathbf{b}$, which was considered as a direct measure of overall dominance was highly significant and thus the said dominance effect was preponderant for total tillers plant ${ }^{-1}$. Genetic component $\mathbf{b}_{1}$ appeared with non-significant value which showed the presence of directional genes for the concerned trait among parents. Highly significant value of genetic component $\mathbf{b}_{\mathbf{2}}$ was responsible for the preponderance distribution of asymmetrical genes among parents whereas specific gene effect $\left(\mathbf{b}_{3}\right)$ yielded significant value for total tillers plant ${ }^{-1}$. Maternal effect (c) showed significant differences. Reciprocal effect (d) appeared with significant. When data was subjected to scaling tests for adequacy for the trait it was found adequate for total tillers plant ${ }^{-1}$ (Table 4). Estimates of genetic components of variations $\mathrm{D}, \mathrm{F}, \mathrm{H}_{1}, \mathrm{H}_{2}, \mathrm{~h}^{2}$ and $\mathrm{E}$ are presented in
Table 5. Estimates of genetic components of variation for, spike length, tillers plant ${ }^{-1}$, spikelets spike ${ }^{-1}$ and phytic acid.

\begin{tabular}{|c|c|c|c|c|c|c|c|c|}
\hline \multirow[t]{2}{*}{ Components } & \multicolumn{2}{|c|}{$\begin{array}{c}\text { Phytic } \\
\text { acid }\end{array}$} & \multicolumn{2}{|c|}{$\begin{array}{l}\text { Spike } \\
\text { length }\end{array}$} & \multicolumn{2}{|c|}{$\begin{array}{c}\text { Spikelets } \\
\text { spike }^{-1}\end{array}$} & \multicolumn{2}{|c|}{$\begin{array}{c}\text { Total tillers } \\
\text { plant }^{-1}\end{array}$} \\
\hline & MS & SE & MS & SE & MS & SE & MS & $\mathbf{S E}$ \\
\hline $\mathrm{D}$ & $0.89^{*}$ & \pm 0.26 & $1.26^{\mathrm{NS}}$ & \pm 1.00 & $1.43^{\mathrm{NS}}$ & \pm 0.98 & $0.33^{\mathrm{NS}}$ & \pm 1.28 \\
\hline $\mathrm{H}_{1}$ & $2.43^{*}$ & \pm 0.46 & $2.40^{\mathrm{NS}}$ & \pm 1.36 & $2.90^{*}$ & \pm 1.26 & $3.73^{\mathrm{NS}}$ & \pm 2.24 \\
\hline $\mathrm{H}_{2}$ & $1.80^{*}$ & \pm 0.33 & $2.41^{*}$ & \pm 1.20 & $1.09^{\mathrm{NS}}$ & \pm 1.29 & $1.30^{\mathrm{NS}}$ & \pm 2.12 \\
\hline $\mathrm{F}$ & $1.50^{*}$ & \pm 0.39 & $0.79^{*}$ & \pm 1.15 & $3.84^{*}$ & \pm 1.74 & $4.89^{\mathrm{NS}}$ & \pm 3.06 \\
\hline$h^{2}$ & $0.777^{*}$ & \pm 0.40 & $7.8^{*}$ & \pm 3.09 & $0.05^{\mathrm{NS}}$ & \pm 0.72 & $0.72^{\mathrm{NS}}$ & \pm 1.89 \\
\hline $\mathrm{E}$ & $0.07^{*}$ & \pm 0.01 & $0.49^{*}$ & \pm 0.10 & $0.45^{*}$ & \pm 0.09 & $0.93^{* *}$ & \pm 0.18 \\
\hline$\left(\mathrm{H}_{1} / \mathrm{D}\right)^{1 / 2}$ & 1.65 & & 1.37 & & 1.69 & & 3.80 & \\
\hline $\begin{array}{l}\left(4 \mathrm{DH}_{1}\right)^{1 / 2}+\mathrm{F} / \\
\left(4 \mathrm{DH}_{1}\right)^{1 / 2}-\mathrm{F}\end{array}$ & 0.75 & & 0.25 & & 0.18 & & 0.19 & \\
\hline Heritability (ns) & 0.01 & & 0.61 & & 0.61 & & 0.75 & \\
\hline Heritability (bs) & 0.86 & & 0.17 & & 0.35 & & 0.05 & \\
\hline
\end{tabular}

${ }^{*}=$ value is significant when it exceeds 1.96 after dividing by its standard error.

Table 5. Non-significant differences were found for D. Both $\mathrm{H}_{1}, \mathrm{H}_{2}$ genetic components showed non-significant differences; however, their values were greater than $\mathrm{D}$ which showed that the total tillers plant ${ }^{-1}$ was under the control of dominant genes. Genetic component $F$ was positive and non-significant which indicated the occurrence of dominant genes and it was also confirmed by the ratio of dominant to recessive genes $(0.75)$ which was less than unity. Average degree of dominance $\left(\mathrm{H}_{1} / \mathrm{D}\right)^{1 / 2}$ was greater than unity which supported over dominance type of gene action for the said trait. Environmental component was significant which played greater role in the expression of total tillers plant ${ }^{-1}$. Estimated values of narrow sense heritability were 0.05 and broad sense heritability 0.52 , respectively for total tillers plant ${ }^{-1}$ (Table 5). Our results are supported by $[18,19]$ who reported dominance type of gene effect for total tillers plant ${ }^{-1}$.

\subsubsection{Spikelets Spike ${ }^{-1}$}

Formal diallel analysis for spikelets spike ${ }^{-1}$ was conducted by using Dial-98 software which revealed significant differences for item $\mathbf{a}$, which was the measure of additive gene effect and accounted for high proportion of the total variation (Table 3). Genetic component b which was used for the direct measurement of overall dominance was also highly significant, expressing the fundamental contribution for dominance. Non-significant value of $\mathbf{b}_{1}$ genetic component showed the lack of directional genes for spikelets spike ${ }^{-1}$. Highly significant value of component $\mathbf{b}_{2}$ was held accountable for the allocation of asymmetrical genes among parents whereas significant value of $\mathbf{b}_{3}$ accounted for the existence of specific gene effect. The value of c (maternal effect) was highly significant. Reciprocal effect (d) was also significant. Data of spikelets spike ${ }^{-1}$ was found partially adequate after sub- 
jecting to adequacy tests of additive dominance model (Table 3). Estimates of genetic components of variations (Table 5) for spikelets spike ${ }^{-1}$ in $F_{1}$ hybrids revealed non-significant value for $\mathrm{D}$ component which showed that spikelets spike ${ }^{-1}$ was not controlled by additive gene effect. Significant value of $\mathrm{H}_{1}$ was responsible for dominance due to dominant genes. Positive and significant value of genetic component $\mathrm{F}$ indicated presence of dominant genes for the said trait. The average degree of dominance $\left(\mathrm{H}_{1} / \mathrm{D}\right)^{1 / 2}$ value was 1.69 indicating over dominance type of gene action for spikelets spike ${ }^{-1}$. Heritability estimates in narrow sense were 0.35 and that of broad sense were 0.74 and for spikelets spike ${ }^{-1}$ (Table 5). These results are in line with $[17,20]$, who had reported over dominance type of gene action for spikelets spike ${ }^{-1}$. [21] had reported additive type of gene action for spikelets spike ${ }^{-1}$.

\subsection{Phytic Acid}

Diallel analysis for $5 \times 5$ diallel cross was carried out by using Dial-98 statistical package for phytic acid which revealed (Table 3) non-significant variation for genetic component a which is the of measure of additive gene effect. Genetic component $\mathbf{b}$, for over all dominance was highly significant, indicating the importance of dominance Genetic component $\mathbf{b}_{1}$ accounted for directional genes distribution among parent was also found significant for the said trait. Distribution of asymmetrical genes $\left(\mathbf{b}_{2}\right)$ among parents and existence of specific gene effect $\left(\mathbf{b}_{3}\right)$ for phytic acid were also recorded with significant differences. Maternal effect (c) and reciprocal effect (d) score was also significant for phytic acid. Additive dominance model was adequate for phytic acid due to nonsignificant values of $\mathrm{t}^{2}$ test and regression analysis (Table 4). Estimation for genetic components of variations, D, $\mathrm{H}_{1}, \mathrm{H}_{2}, \mathrm{~F}, \mathrm{~h}^{2}$ and $\mathrm{E}$ revealed significant differences (Table 5). Variance of additive gene effect was significant, but its value was less than both $\mathrm{H}_{1}$ and $\mathrm{H}_{2}$ indicating a lesser role of additive genes than dominance for phytic acid. Value of $\mathrm{H}_{1}$ was a little bit greater than $\mathrm{H}_{2}$ indicating more contribution of dominant genes. Value of $\mathrm{F}$ genetic item was significant and positive showing the existence of dominant genes for controlling phytic acid. Mean degree of dominance $\left(\mathrm{H}_{1} / \mathrm{D}\right)^{1 / 2}$ was equal to 1.65 which was clear confirmation that phytic acid concentration in wheat kernels was under the control of over dominant type of gene action. Significant score of $h^{2}$ indicated existence of overall dominance effect due to heterozygous loci supporting that phytic acid was under the control of dominant genes. Narrow sense 0.01 and broad sense 0.86 heritability estimates were found for phytic acid (Table 5). These results are in close agreement with the findings of [22] who had reported variation in phytic acid concentrations levels in different cul- tivars of bread wheat and same cultivar of bread wheat at different locations. [23] also depicted similar findings and suggested that the comprehensive evaluation of wheat germplasm for phytic acid content should be conducted in multi-environments. It is therefore suggested that phytic acid contents in wheat should be controlled as much influenced by environments to save an increasing number of breast cancer patients. The United States Food and Drug Administration have listed phytic acid among the 187 fake cancer "cures" consumers should avoid [24, $25]$.

\section{CONCLUSION}

It was concluded from the present study that some of the $\mathrm{F}_{1}$ hybrids like Ps-2005 $\times$ Ghaznavi (0.56\%), AUP-4006 $\times$ Ps-2004 $(0.74 \%)$, Janbaz $\times$ Ps-2004 $(0.89 \%)$ and Janbaz $\times$ Ps-2005 (1.01\%), had the lowest concentration of phytic acid. This research confirms that $\mathrm{F}_{1}$ hybrids with low phytic acid concentration could yield desirable segregants.

\section{REFERENCES}

[1] Noorka, I.R. and Shahid, S.A. (2013) Use of conservation tillage system in Semiarid Region to ensure wheat food security in Pakistan, Development in Soil Salinity Assessment and Reclamation, Springer Book, 2013.

http://www.springer.com/environmrnt/soil+science/book/ 978978-94-007-5683-0

[2] Noorka, I.R., Batool, A., AlSultan, S., Tabasum, S. and Ali, A. (2013) Water stress tolerance, its relationship to assimilate partitioning and potence ratio in spring wheat. American Journal of Plant Sciences, 4, 231-237. doi:10.4236/ajps.2013.42030

[3] Noorka, I.R. Rehman, S., Haidry J.R., Khaliq, I., Tabassam, S. and Din, M. (2009) Effect of water stress on physico-chemical properties of wheat (Triticum aestivum L.). Pakistan Journal of Botany, 41, 2917-2924.

[4] Noorka, I.R. and Haidery, J.R. (2011) Conservation of genetic resources and enhancing resilience in water stress areas of the Pakistan to cope with vagaries of climate change. In: Rang, A., et al. (Eds.), International Conference Preparing Agriculture for Climate Change, Ludhiana, 6-8 February 2011, pp. 106-107.

[5] Rehman, S.U., Anjum, S.A. and Anjum, F.M. (2006) Storage stability of ferrous iron in whole wheat flour naan production. Journal of Food Processing and Preservation, 30, 323-334. doi:10.1111/j.1745-4549.2006.00068.x

[6] Saneoka, H., Takeshi, H., Akihiro, Y., Nobuhiro, N., Tomio, I. and Kounosuke, F. (2006) Changes in the composition of phytic acid, phosphorus and other cations in soybean seeds with maturity. Grassland Science, 52, 99104. doi:10.1111/j.1744-697X.2006.00054.X

[7] Reale, A., Mannina, L., Tremonte, P., Sobolev, A.P., Succi, M., Sorrentino, E. and Coppola, R. (2004) Phytic acid degradation by lactic acid bacteria and yeasts during the whole-meal dough fermentation. Journal of Agricul- 
tural and Food Chemistry, 52, 6300-6305. doi:10.1021/jf049551p

[8] Szkudelski, T. (2005) Phytic acid induced metabolic changes in the rat. Journal of Animal Physiology and Animal Nutrition, 89, 397-402. doi:10.1111/j.1439-0396.2005.00532.x

[9] Noorka, I.R. and Teixeira da Silva, J.A. (2012) Mechanistic insight of water stress induced aggregation in wheat (Triticum aestivum L.) quality: The protein paradigm shift. Notulae Scientia Biologicae, 4, 32-38.

[10] Haug, W. and Lantzsch, H.J. (1983) Sensitive method for the rapid determination of phytic acid in cereals and cereals products. Journal of the Science of Food and Agriculture, 34, 1423-1426. doi:10.1002/jsfa.2740341217

[11] Steel, R.G.D., Torrie, J.H. and Dicky, D.A. (1997) Principles and procedures of statistics. A biological approach. McGraw Hill Brook Co., New York, 336-354.

[12] Hayman, B.I. (1954) The theory and analysis of diallel crosses. Genetics, 39, 789-809.

[13] Khan, I. and Khalil, I.H. (2006) Selection response for yield and yield related traits in bread wheat. M.Sc. Thesis, University of Agriculture, Faisalabad.

[14] Lonc, W. (1989) Types of gene effects governing quantattive characters in winter wheat. Hodawla Roslin, Akiimatyazacja I Nasiennictwo, Poland, 29, 1-11.

[15] Noorka, I.R., Batool, A., Rauf, S., Teixeira da Silva, J.A. and Ashraf, E. (2013) Estimation of heterosis in wheat (Triticum aestivum L.) under contrasting water regimes. International Journal of Plant Breeding, 7, 55-60.

[16] Li, L.Z., Lu, D.B. and Cui, D.Q. (1991) Study on the combining ability for yield and quality characters in winter wheat. Acta Agriculture. Universitatis Henaanesis, 25. 372-378.

[17] Iqbal, M., Alam, K. and Chowdhry, M.A. (1991) Genetic analysis of plant height and the trait above the flag area node in bread wheat. Sarhad Journal of Agriculture, 7,
131-134.

[18] Bebyakin, V.M. and Tsitologlya, N.I. and Korobova, I.G. (1989) Gene interaction and combining ability effects of winter wheat varieties for yield components. Tsitologlya $i$ Genetica, 23, 23-26.

[19] Prodanovic, S. (1993) Genetic values of F1 wheat hybrids obtained in diallel crosses. Review of Research Work at the Faculty of Agriculture, Belgrade, 38, 25-37.

[20] Haug, W. and Lantzsch, H. (2006) Sensitive method for the rapid determination of phytate in cereals and cereal products. The Journal of the Science of Food and Agriculture, 34, 1423-1426. doi:10.1002/jsfa.2740341217

[21] Rasal, P.N., Patil, H.S., Chavan, V.W. and Manake, B.S. (1991) Combining ability studies for certain quantitative traits in wheat. Journal of Maharashtra Agricultural Universities, 16, 206-208.

[22] Masud, T., Mahmood, T., Latif, A., Sammi, S. and Hameed, T. (2007) Influence of processing and cooking methodologies for reduction of phytic acid content in wheat (Triticum aestivum) varieties. Journal of Food Processing and Preservation, 31, 583-594. doi:10.1111/j.1745-4549.2007.00147.x

[23] Khan, A.J., Ali, A., Farooq-i-Azam and Aurang Zeb (2007) Identification and isolation of low phytic acid wheat (Triticum aestivum L.) inbred lines/mutants. Pakistan Journal of Botany, 39, 2051-2058.

[24] Dendougui, F. and Schwedt, G. (2004) In vitro analysis of binding capacities of calcium to phytic acid in different food samples. European Food Research and Technology, 219, 409-415. doi:10.1007/s00217-004-0912-7

[25] Bacić, I., Druzijanić, N., Karlo, R., Skifić, I., \& Jagić, S. (2010) Efficacy of IP6 + inositol in the treatment of breast cancer patients receiving chemotherapy: Prospective, randomized, pilot clinical study. Journal of Experimental \& Clinical Cancer Research, 29, 12. doi:10.1186/1756-9966-29-12 